\title{
Improving the Quality of Goat Sperm through the Implementation of Fermented Feed based on Water Hyacinth: Fermege Formula 3
}

\author{
Evie Ratnasari ${ }^{1}$, Herlina Fitrihidajati ${ }^{2}$, Isnawati ${ }^{3}$ \\ Departemen of Biology \\ Uniersitas Negeri Surabaya \\ Surabaya, Indonesia \\ 12evieratnasari@unesa.ac.id, ${ }^{2}$ herlinafitrihidajati@unesa.ac.id, ${ }^{3}$ isnawati@unesa.ac.id
}

\begin{abstract}
Fermented feed made from water hyacinth contain high nutrition, increase goat weight, improve carcass quality and improve the reproduction system of goats. The aims of this study were determining the effect of fermege formula 3 on the quality of goat spermatozoa was compared to conventional feed. This study was experimental research with two treatment were conventional feed as a control and fermege formula 3 feed that gave for two groups of goats. Each treatment with 10 replications. The goat in this research was given each kind of feed 2 times each day for 12 weeks in the morning and evening as much as $2 \%$ of the body weight of goats. Parameters were observed in this research was the sperm quality included macroscopic aspects (volume, odor, color, pH, viscosity) and microscopic (viability, mass and individual motility). The results of this study indicate that the quality of goat sperm in macroscopic aspects in both treatments did not show differences except in the viscosity parameter. However, on the microscopic aspects of goat sperm with fermege formula 3 was better than goat sperm with conventional feed.
\end{abstract}

Keywords-Fermented Feed, Water Hyacinth, Sperm Goat

\section{INTRODUCTION}

The composition of nutritious feed was improved continuously to get the profits of the goat breeding business. Water weed materials such as water hyacinth, water spinach and other waste like tofu dregs are the best choices to use. Water hyacinth has been known to contain high nutrients. Water hyacinth contains about $7 \%$ dry matter; crude protein $11.2 \%$; crude fiber $18.3 \%$; BETN $57 \%$; crude fat $0.9 \%$; ash 12.6\%; Ca 1.4\%; and P $0.3 \%$ [1]. Water spinach contains vitamin A (6300 IU / 100g), vitamin B1 (0.07 mg / 100g), vitamin C (32 mg / 100g), protein ( $3 \mathrm{~g} / 100 \mathrm{~g})$, calcium (73 $\mathrm{mg} / 100 \mathrm{~g})$, phosphorus (50 mg / 100g), iron (3 mg / $100 \mathrm{~g}$ ), fat $(0.3 \mathrm{~g} / 100 \mathrm{~g})$, and carbohydrates $(5.4 \mathrm{~g} / 100 \mathrm{~g})$. Tofu dreg contain $8.66 \%$ protein, $3.79 \%$ fat, $51.63 \%$ water and $1.21 \%$ ash, so it is very possible to use the waste in food livestock production [2]. In production of fermented feed, molasses was commonly to increase the nutritional value of feed. Molasses can be divided into two groups, namely: (1) Cane-molasses, is molasses which contains sucrose $25-40 \%$ and $12-25 \%$ reducing sugar with a total sugar content of 50 -
$60 \%$ or more. Crude protein content (PK) is around $3 \%$ and ash content is around $8-10 \%$, which is built by potassium, calcium, chloride and sulfate salts; (2) Beet-molasses is a normal laxative feed is given to livestock in a small amount of about $0.5 \%$ [3]. These ingredients support the body growth and reproduction activities of goats. Digestive systems and feed digestibility will affect feed consumption. Fast digestive systems and high digestibility will increase feed consumption [4].

In this study, the implementation of fermented feed that named "fermege formula 3" was given to sample goats to improve the sperm quality. This research is a continuation of similar research that has been carried out several years earlier. Fermentation techniques that is applied in this research followed the best results of previous studies [5] and [6]. Actually, the best feed formula is called "fermege formula 3" was discovered by Suparno [7]. The results of these experiment it was explaining that Saccharomyces cerevisiae in fermentation process could increase digestibility to organic substance compared to conventional feed [8].

\section{MATERIALS AND METHOD}

The tools was used in this research were chopper, $10 \mathrm{cc}$ syringe, 3 cc syringe, transparent plastic bag, $10 \mathrm{~L}$ water, and $30 \mathrm{cc}$ measuring cup, large cormorant, large basket, gas stove, microscope, artificial vagina, micropipette, haemocytometer, paper $\mathrm{pH}$ indicator, water bath, enlemeyer, measuring cylinder, glass object, glass lid, spuit, tissue, Bunsen Burner. Ingredients that was used in this study were water hyacinth and water spinach that is used of all parts of their body $50 \mathrm{~kg}$, molasses $100 \% 300 \mathrm{cc}, 7.5 \mathrm{~L}$ of water, 50 cc probiotics inoculum 7,5 grams, transparent plastic bag and tofu dreg and the fresh sperm.

Fermege production was done by some steps. First step was cutting the water hyacinth and fresh water spinach with a chopper machine $\pm 5 \mathrm{~cm}$ in long. Then, cutted materials was dryed for 2 days in the sun rays until the moisture content is approximately $\pm 20 \%$. The dryed materials was measured $1 \mathrm{~kg}$ for each treatment as much as 50 times and 
was placed in plastic bag. Next step was prepared $750 \mathrm{cc}$ of water in a transparent plastic bag, was added $50 \mathrm{cc}$ liquid probiotics, $300 \mathrm{cc}$ molasses and 0.6 grams of probiotic inoculum (dormant bacteria) in each experimental unit. All of the ingredients were mixed until homogeneous. This ingredient was poured on the water hyacinth and water spinach preparations. The next step was to stir the water hyacinth and water spinach that have been watered with sugarcane drops (molasses), probiotics, and inoculums and was placed in a transparent plastic bag. The ingredients were fermented for 5 days. After fermented feed has been made, fermege formula 3 (tofu dreg $35 \%$, fermented water hyacinth $35 \%$, rending water spinach $30 \%$ ) will be made, then testing the complete proksimat contents to the quality of fermege formula 3 feed and the result is crude protein $7,3 \%$, crude fat $3,7 \%$, crude fiber $16,5 \%$, and BETN $17,7 \%$ so that it can be concluded that the nutrient contents of fermege formula 3 is enough to fulfill the nutrition needs for sample goat's growth. Then the implementation of feeding treatment to 10 male goats with fermege formula 3 and with conventional feed to other 10 male goats. The feed implementation to the male goats was done twice a day in the morning and afternoon for 12 weeks as much as $2 \%$ of the goat's body weight. Finally, was measure the productivity of male goats, namely macroscopic sperm quality (volume, color, odor, viscosity and $\mathrm{pH}$ ) and microscopic sperm quality (concentration, mass motility, individual motility, viability and concentration). The data were analyzed by quantitative descriptive

\section{RESULTS AND DISCUSSION}

The results of the study were obtained data about sperm quality from the macroscopic and microscopic aspects.

\section{A. Quality of goat sperm macroscopically}

Goat sperm quality based on macroscopic aspects includes volume, color, $\mathrm{pH}$, odor, viscosity and concentration.

TABLE I. COMPARISON OF GOAT SEMEN CHARACTERISTICS MACROSCOPICALLY AT DIFFERENT FEED TREATMENTS

\begin{tabular}{|c|c|c|}
\hline \multirow{2}{*}{ Parameter } & \multicolumn{2}{|c|}{ Kinds of feed } \\
\cline { 2 - 3 } & Conventional & Fermege Formula 3 \\
\hline Volume & $1 \mathrm{ml}$ & $1 \mathrm{ml}$ \\
\hline Odor & Sperm & Khas \\
\hline Color & Creamy & Creamy \\
\hline $\mathrm{pH}$ & 6.6 & 6.5 \\
\hline Viscosity & ++ & +++ \\
\hline
\end{tabular}

The research started by took a sperm goat (Fig. 1.). The average of sperms volume beetwen goats with conventional feed and that with fermege formula 3 feed was the same 1 $\mathrm{ml}$. Goat sperm volume varies around $0,1-1,5 \mathrm{ml}$, it means that fermege formula 3 has fulfill the sperm quality criteria by Jainudeen.

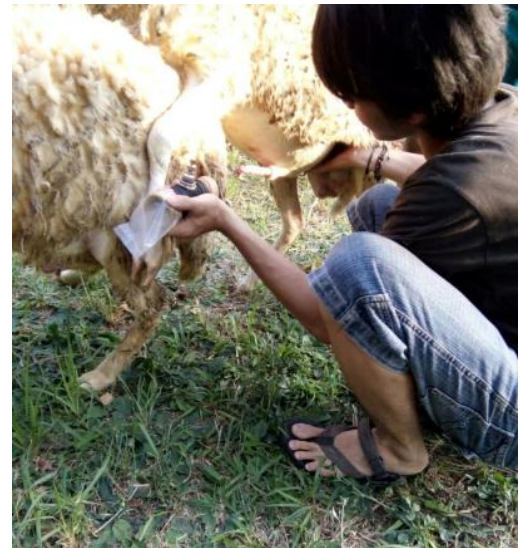

Fig. 1. Process of taking goat sperm.

There is no difference of sperm quality in the macroscopic aspect, except for viscosity parameters. The sperm viscosity of goat with fermege formula 3 had a great viscous than conventional feed. This means that fermege formula 3 feed can replace conventional feed without affecting the reproduction system of the goat. Likewise, sperm quality in terms of odor, color, $\mathrm{pH}$ of the two groups of goats had the same quality. The sperm color was white, the standart of good sperm had white colour and did not translucent [9]. The viscosity of the goat's sperm feed fermege is higher than the viscosity of the goat sperm given by conventional food. This means that the number of spermatozoa in goat sperm with fermege formula 3 feed was higher than that of conventional feed. This is due to containing of fermege formula 3 that contain high protein which is the precursor to the formation of spermatozoa cells. The $\mathrm{pH}$ level was highly affecting to sperms's viability the goat's sperm had $\mathrm{pH}$ average around $6,2-7,0$ or 6,8 , the standard was claimed by Hafeez [10]. The average $\mathrm{pH}$ level results from the experiment was around 6,5. It was suspected because of the fermege formula 3 was given to the goats could support the metabolism of spermatozoa went normally.

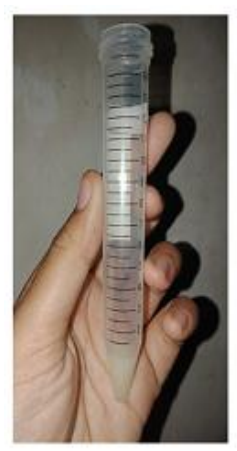

(A)

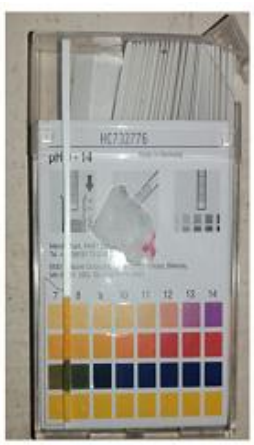

(B)

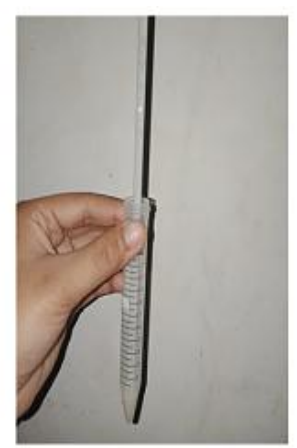

(C)
Fig. 2. (A) Goat semen volume measurement; (B) Goat semen $\mathrm{pH}$ measurement $(\mathrm{C})$ Goat semen temperature measurement (Source: Personal documentation, 2018). 
B. Quality of goat sperm microscopically

Goat sperm quality based on microscopic aspects include mass motility, individual motility, concentration and viability.

TABLE II. COMPARISON OF GOAT SPERM CHARACTERISTICS MICROSCOPICALLY IN DIFFERENT FEED TREATMENTS.

\begin{tabular}{|l|c|c|}
\hline \multirow{2}{*}{ Parameter } & \multicolumn{2}{|c|}{ Kind of feed } \\
\cline { 2 - 3 } & Conventional & Fermege Formula 3 \\
\hline Mass motility & ++ & +++ \\
\hline Individual motility & 80,5 & 87,75 \\
\hline Concentration & $2,7 \times 10^{6}$ & $2 \times 10^{6}$ \\
\hline Viability & 83 & 89 \\
\hline
\end{tabular}

The motility of spermatozoa was ability of spermatozoa movement and divided to mass motility and individu motility. The mass motility of sperm with fermege formula 3 had some characteristic, it was looked like big bold waves that moving around fastly $(+++)$. But the mass motility of sperm with conventional food had some characteristics, it was looked like the small waves that moving slowly(++). As we could see from the appearer of the mass motility, the sperm that feed with fermege formula 3 had a better quality than conventional feed. The individual motility could be seen by percentage, the fermege formula 3 had $87,75 \%$ but the conventional feed has lower percentage it was $80,5 \%$. The motility of the goat sperm with fermege formula 3 better than that with conventional feed and also better than the ideal standard. There were 2 factors that influenced the motility of spermatozoa it was endogen factors (age, spermatozoa maturation, availability of energy, survive against foreign objects) and exogen factors (environment, stimulants, and inhibtors) [11]

Fermege formula 3 feed contained a high source of energy. The results of complete proximate test showed that the quality of the fermege formula 3 was contained by $7.3 \%$ crude protein, $3.7 \%$ crude fat, $16.5 \%$ crude fiber and $17.7 \%$ BETN. Protein that contained in fermege formula 3 can increased a life percentage and influenced the intensity of membran plasma spermatozoa [12]. From the results above, can be concluded that nutritional content of Fermege formula 3 feed was better than conventional feed. These nutrient supplied sperm cells to move quickly, and have high sperm of motility [13]. The ideal standard for goat sperm motility is $\geq 70 \%$ [14].

The source of energy contained in fermege formula 3 came from the degradation of carbohydrates and fats through the digestive systems of ruminant animals. Likewise, the viability of spermatozoa was very dependent on energy supply as well as motility. The ideal standard of viability for fresh goat sperm is $\geq 50 \%$ thus the viability of goat sperm with fermege formula 3 .

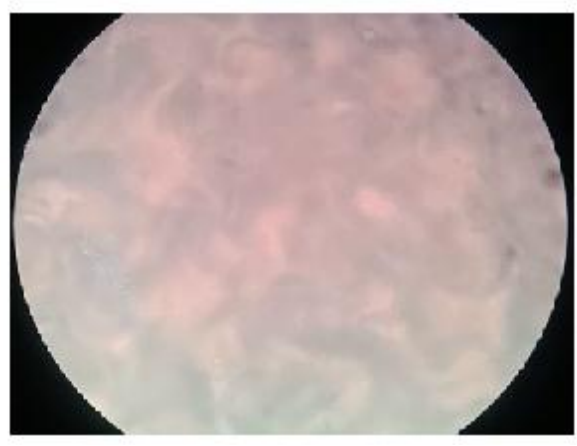

(A)

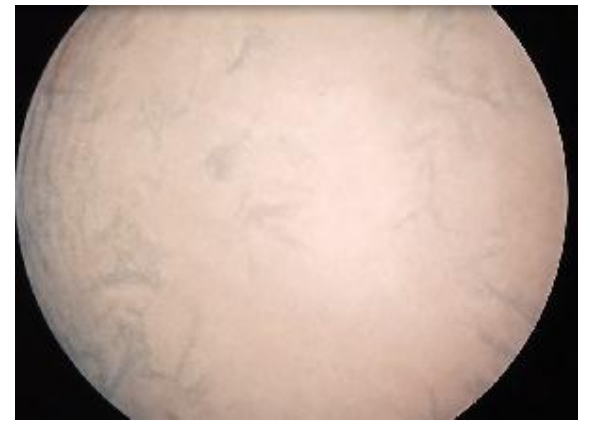

(B)

Fig. 3. Male goat's sperm mass motility (A) fermege formula 3 feed section (B) conventional feed (magnification 40x10) (Source: Personal documentation, 2018).

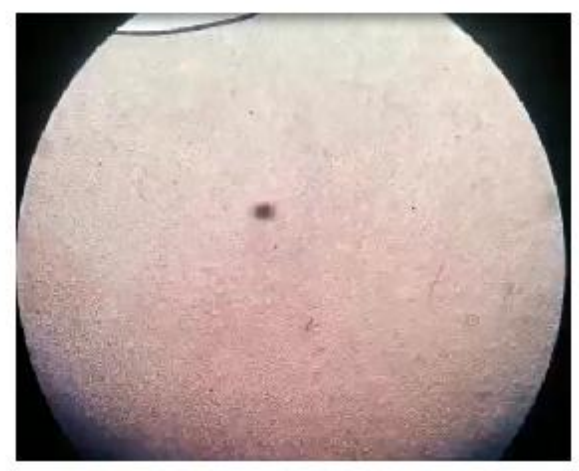

(A)

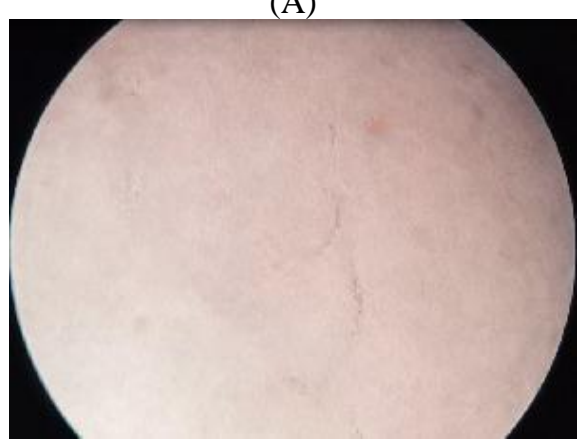

(B)

Fig. 4. Male goat's sperm individual motility (A) fermege formula 3 feed section (B) Conventional Feed (magnification 40x10) (Source: Personal documentation, 2018). 
Concentration of sperm was also important characteristic, if the concentration had a high value so the quality of sperm was also high [15]. The Viability of spermatozoa was a life percentage of spermatozoa, it could be seen by eosin negrosin coloring. Eosin negrosin that gave to spermatozoa would enter the cell was had a high membran permeable, the life cells would ignore the eosin nigrosin that's why head of spermatozoa did not absorb the color [16]. The life percentage of spermatozoa depends on the integrity of membran spermatozoa, if the membran was broken it can cause the intraseluler metabolism being unstable and the spermatozoa would be weak and dead. The results showed that the viability sperm with fermege formula 3 had a better quality than with conventional feed.

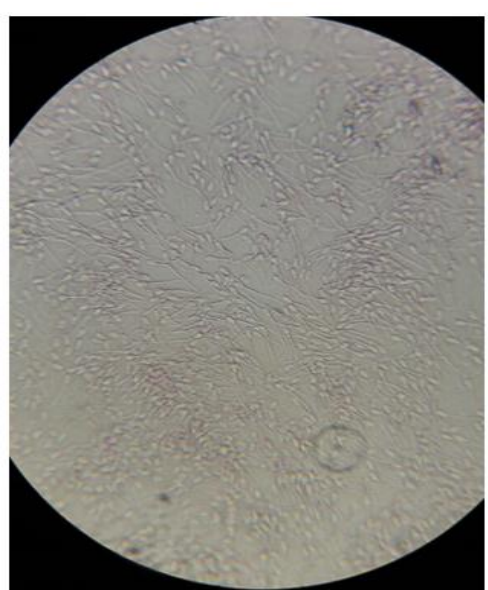

(A)

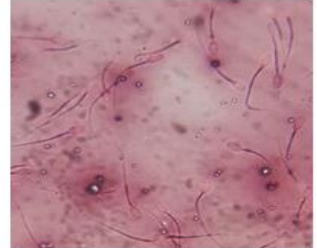

(B)

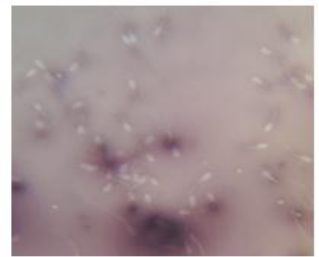

(C)
Fig. 5. (A) Male goat's sperm viability with fermege formula 3 feed section (magnification 40x10); (B) Died sperms; (C) Living sperms (Source: Personal document 2018).

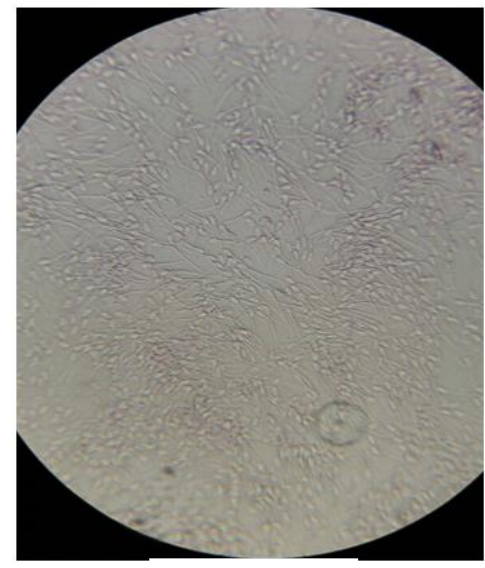

(A)

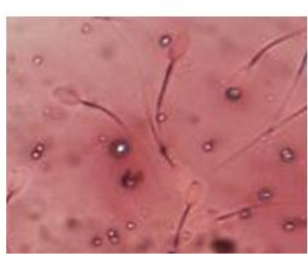

(B)

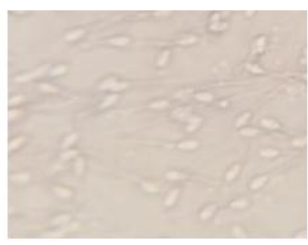

(C)
Fig. 6. (A) Male goat's sperm viability with conventional feed section (magnification 40x10); (B) Died sperms; (C) Living sperms (Source: Personal documentation, 2018).

\section{CONCLUSION}

The results of this study indicate that the quality of goat sperm in macroscopic aspects in both treatments did not show differences except in the viscosity parameter. However, on the microscopic aspects of goat sperm with fermege formula 3 had better quality than goat sperm with conventional feed.

\section{REFERENCES}

[1] Tristiarti, Kecernaan Nutrien Eceng Gondok yang difermentas dengan Aspergilus niger pada Ayam Broiler, 2006. Diakses melalui http://eprints.undip.ac.id/6888/1/oke31(2)2006p124-128.pdf, pukul 13.00 WIB.

[2] Dinas Peternakan Propinsi Jawa Timur, Uji Coba Pembuatan Silase Ampas Tahu, Jawa Timur, 2011.

[3] P.R.A McDonald, Edwards, and J.F.D. Greenhalg, Animal Nutrition 6nd Ed. Longman Scientificand Technical, John Willey and Sons Inc., NewYork, 2002, pp. 90-95.

[4] H. Fitrihidajati, E. Ratnasari, Isnawati. Kualitas Hasil Fermentasi pada Pembuatan Pakan Ternak Ruminansia Berbahan Baku Eceng Gondok (Eichornia crassipes). Biosaintifika vol. 7, pp. 62-67, 2015.

[5] H. Fitrihidajati, Isnawati dan G. Suparno, Pemanfaatan Eceng Gondok (Eichornia crassipes) untuk Pakan Ternak Ruminansia sebagai Salah Satu Cara Mengatasi Gulma Perairan, Laporan Penelitian Hibah Bersaing Lanjutan, Universitas Negeri Surabaya, 2014.

[6] Fitrihidajati, H., Isnawati, dan G.Suparno. 2013.Pemanfaatan Eceng Gondok (Eichornia crassipes) untuk Pakan Ternak Ruminansia sebagai Salah Satu Cara Mengatasi Gulma Perairan. Laporan Penelitian Hibah Bersaing. Universitas Negeri Surabaya.

[7] M.R. Jainudeen, and E.S.E. Hafez. Sheepand goat. In: Reproduction in Farm Animals.Seventh Edition, HAFEZ, E.S.E. and B. HAFEZ.(Eds.), Lippincott Williams \& Wilkins, Baltimore, 2000.

[8] A.M.A. Fadel, "Effect of Supplemental Yeast (Saccharomyces cerevisiae) Culture on NDF Digestibility and Rumen Fermentation of Forage Sorghum Hay in Nubian Goat's Kids," J. Agric. And Biol. Sci., vol. 3, pp. 133-137, 2007.

[9] I. Supriatna, Inseminasi Buatan pada Ayam. Kegiatan Pelatihan Inseminasi Buatan pada Ayam. Laboratorium Ladang Terpadu, Fakultas Kedokteran Hewan, Institut Pertanian Bogor, 2000.

[10] E.S.E. Hafez, Semen Evaluation in Reproduction In FarmAnimals 7 the edition. Maryland, USA: Lippincott Wiliams and Wilkins, 2008.

[11] D.L. Garner, and E.S.E. Hafez, Spermatozoa and Seminal Plasma. In: Hafez B, Hafez ESE. Reproduction in Farm Animals, 7th ed., Lea and Febiger: Philadelphia (US), 2000.

[12] A.A. Dethan, Kustono, and H. Hartadi, "Kualitas dan kuantitas sperma kambing Bligon jantan yang diberi pakan rumput gajah dengan suplementasi tepung darah,” Bul Peter., vol. 34, pp. 145-153, 2010.

[13] F. A. Pamungkas, F. Mahmilia dan S. Elieser, "Perbandingan karakteristik semen kambing Boer dengan Kacang," Sem. Nas. Tek. Peter. Veter., 2008, pp. 367-370.

[14] T.W. Perry, A.E. Cullison and R.S. Lowrey Feed \& Feeding. 6n Ed Pearson Education, Inc., Upper SaddleRiver, New Jersey, 2003.

[15] E.S.E. Hafez, Reproduction In Farm Animals. Lea and Febiger: Philadelphia 1993.

[16] J.K. Graham, Assessment of sperm quality, Proceendings of the anual convention of the AAEP-2001. Vol. 47, pp. 302-305, 2001. 